Cronfa - Swansea University Open Access Repository

This is an author produced version of a paper published in :

Policy \& Politics

Cronfa URL for this paper:

http://cronfa.swan.ac.uk/Record/cronfa33877

\title{
Paper:
}

Burnett, J. (2007). Britain's 'civilising project': community cohesion and core values. Policy \& Politics, 35(2), 353-357. http://dx.doi.org/10.1332/030557307780713004

This article is brought to you by Swansea University. Any person downloading material is agreeing to abide by the terms of the repository licence. Authors are personally responsible for adhering to publisher restrictions or conditions. When uploading content they are required to comply with their publisher agreement and the SHERPA RoMEO database to judge whether or not it is copyright safe to add this version of the paper to this repository. http://www.swansea.ac.uk/iss/researchsupport/cronfa-support/ 


\section{Britain's 'civilising project': community cohesion and core values}

Multiculturalism in Britain is under attack. At the beginning of the new year, Gordon Brown took the opportunity to reinvigorate a national debate on multiculturalism as a source of internal tension and divisions. And in what has now become a familiar mantra, he claimed that:

Continually failing to emphasise what bound us together as a country, multiculturalism became an excuse for justifying separateness and then separateness became a tolerance of - and all too often a defence of - even greater exclusivity. (cited in Johnston, 2007)

The Chancellor of the Exchequer is not alone in this view, and a wideranging coalition of think-tanks, journalists and scholars have reiterated the perception that diversity threatens national stability (see, for example, West, 2005). Perhaps most tellingly, this view has underpinned a form of hegemony through which the main political parties in the country have formed a consensus. Only weeks after Gordon Brown reiterated his views, the Leader of the Opposition, David Cameron, (2007) produced what was nearly a carbon copy of his comments and maintained that ' $[\mathrm{t}]$ he doctrine of multiculturalism has undermined our nation's sense of cohesiveness because it emphasises what divides us rather than what brings us together'. As Sivanandan (2006a: 3) has acutely noted, multiculturalism 'has become the whipping boy'.

This attack on multiculturalism has its roots in the series of urban disorders that occurred in northern towns and cities in 2001. Throughout that summer bitter fighting occurred, most visibly in Oldham, Bradford and Burnley, predominantly between white and Asian youths, and the police (see Home Office, 2001). In response, a wide-ranging official investigation led by civil servant Ted Cantle (the Cantle Report) claimed that the violence was indicative of a nation of communities leading 'parallel lives' (Cantle, 2001: para 2.1). In turn, this 'reading' of the disorders - which downplayed the role of far-Right activity in stoking the violence suggested that it was necessary to instil a set of core values among citizens in order to foster unity. 'It is necessary', Cantle suggested, 'to establish a greater sense of citizenship, based on (a few) common principles which are shared and observed by all members of the community' (Cantle, 2001: para 2.13).

Since its publication the Cantle Report has become the blueprint for a formal shift in race relations policy and practice (see Burnett, 2004). In policy terms, multiculturalism has begun to be replaced by a community cohesion agenda that sets out to define the boundaries of diversity and, as such, has given political impetus to the attack on multiculturalism. At the heart of this movement is a desire to instil codes of behaviour among citizens, and indeed would-be citizens, and redefine a sense of national identity. Consequently, citizenship tests and swearing allegiance to the Queen and nation are now compulsory for those who wish to gain citizenship in the country, 1 and the aims of citizenship education and the teaching of 'Britishness' in schools has become the source of national debate (see, for example Garner, 2007: 25).

At the heart of such attempts to instil core values among those who reside, or wish to reside, in Britain is a distorted resurrection of discredited underclass theories; in other words, policies, politics and, to a certain extent, social contexts are downplayed in favour of a theory 
that seeks to describe a range of conflicts and tensions through a perception of the lack of core values. This is particularly visible in the context of the 'war on terror' (see Burnett, 2005), which, if not framed by the belief in a 'clash of civilisations' is framed by the belief of a 'clash about civilisation' (Blair, 2006) that sets out the framing of core values as a way in which to establish stability and unity. One of the consequences of this is that in a context where the very role of Britain in global affairs is of central concern - not least through the actions of the country in the deeply unpopular 'war on terror' - 'Britishness' has been manifested as a banner around which to foster core values at home. Gordon Brown made this clear in a debate in the New Labour think-tank, the Fabian Society, in 2005, and claimed that 'the days of Britain having to apologise for the British Empire are over. We should celebrate' (cited in Pilger, 2006: 6).3

As the Institute of Race Relations has powerfully maintained, this shift to community cohesion should consequently be understood as a move to cultural homogenisation (see Campaign Against Racism and Fascism, 2002; and Fekete, 2004). Moreover, this homogenisation is enforced (Sivanandan, 2006b). Where the community cohesion agenda attempts to instil values in individuals and communities it is supported by increasing criminal justice and anti-terrorism powers, which, crucially, extend to the 'policing' of citizenship and belonging. Thus, for example, in 2005 new powers to deport non-UK citizens were consolidated through a particularly vague notion of their presence as being 'not conducive to the public good'. Examples of this included those who were decided to be threatening to the 'UK's good relations with a third country', public speaking and using a position of responsibility, such as that of a teacher (Home Office, 2005:1-3). In this vein, in 2006 Tony Blair bluntly told Muslims that 'Our tolerance is part of what makes Britain, Britain. Conform to it; or don't come here' (cited in Woodward, 2006). 'The path to the authoritarian state' as Waters (2004: 2) has suggested, 'leads through the security gates'.

What is being witnessed, then, is something akin to a civilisational project, which aims to instil values among those who are deemed to be a threat, or potential threat, to a given definition of community cohesion. Yet this agenda cannot be separated from the wider context in which it has been invigorated. Nor can it be separated from the directly coercive actions from which it maintains support. For it is through these wider contexts that community cohesion can be understood as a euphemism for integration; and integration a euphemism for assimilation. As such, while assimilation suggests a form of 'hyper-inclusion' of certain forms of diversity, it also tells us equally about the forms of diversity that will not be recognised or accepted.

In this context, a velvet glove and iron fist analogy is particularly appropriate in that the policies of integration pursued by the New Labour government are supported by increasing scope for coercion. Where community cohesion is utilised to justify an increasing battery of anti-terrorism and criminal justice powers, it also works to justify an increasingly tough immigration and asylum system that bases people's eligibility on their potential to contribute economically. On the one hand, the introduction of a pointsbased, managed migration system explicitly decides whether people can enter Britain based on their economic worth (Home Office, 2006). On the other, a range of policy reforms from the withdrawal of provision for ESOL (English as a Second Language) classes (see Burnett, 2006) to the dramatic cutting of legal assistance for those seeking asylum (see Bail for Immigration Detainees and Asylum 
Aid, 2005), works to make clear that a given understanding of community cohesion seeks to prevent integration, as much as enforcing it.

Ultimately, the community cohesion agenda can be assessed against the form of cohesion that it works to foster. The policy reforms that, apparently, purvey necessary 'core values' at the same time as multiculturalism is blamed for their demise, include the introduction of control orders and a shoot-to-kill policy for suspected terrorists. They also include a managed migration system articulating an understanding of community cohesion based on market dictates, which, as Liz Fekete (2001: 29) has stated, 'allows the rich First World to maintain its economic dominance by emptying the poorer worlds of their skilled workforces'. And they include the end point of an asylum system that enforces destitution on people reminiscent, as Christine Majid (cited in Waites, 2007) has made clear, of 'the days of the 19th century poor laws'.

As Tony Bunyan, the Director of Statewatch, has said (2005, Introduction), if such measures are representative of the core values that are expected to be adhered to in order to protect 'our way of life', then 'I, together with many others, say "Not in my name"'.

Notes 1 Jon Burnett is currently finishing a $\mathrm{PhD}$ on community cohesion at the Centre for Criminal Justice Studies, University of Leeds.

2 The first citizenship ceremony was held on 26 February 2004 (see Home Office, 2004). The pledge reads 'I, (name), (swear by almighty God)/(do solemnly and sincerely affirm) that, on becoming a British citizen, I will be faithful and bear true allegiance to Her Majesty Queen Elizabeth II, her heirs and successors according to law. I will give my loyalty to the United Kingdom and respect its rights and freedoms. I will observe its laws faithfully and fulfil my duties and obligations as a British citizen' (see Travis, 2003).

3 As Paul Gilroy wryly responded: 'When did we start apologising?' (Fabian Society, 2006).

\section{References}

Bail for Immigration Detainees and Asylum Aid (2005) Justice denied: Asylum and immigration legal aid: A system in crisis, London: Bail for Immigration Detainees and Asylum Aid.

Blair, T. (2006) 'Not a clash between civilisations but a clash about civilisation', Speech to the Foreign Policy Centre in association with Reuters, 21 March (http://fpc. org.uk/events/past/231).

Bunyan, T. (2005) 'Introduction', in The war on freedom and democracy: Essays on civil liberties in Europe, London: Spokesman Books/European Civil Liberties Network.

Burnett, J. (2004) 'Community, cohesion and the state', Race and Class, vol 45, no 3: 1-18. Burnett, J. (2005) 'Hearts and minds in the domestic "war on terror"', Campaign Against Racism and Fascism, 18 October (www.carf.demon.co.uk/feat60. html).

Burnett, J. (2006) 'Enforcing the language barrier', Institute of Race Relations News Network, 9 November (www.irr.org.uk/2006/november/ak000009.html).

Cameron, D. (2007) 'No one will be left behind in a Tory Britain', The Observer, 28 January. Campaign Against Racism and Fascism (2002) 'Community cohesion...Blunkett's new race 
doctrine', Campaign Against Racism and Fascism, no 66, February/March (www.carf.demon.co.uk/feat56.html).

Cantle, T. (2001) Community cohesion: A report of the independent review team, London: Home Office.

Fabian Society (2006) 'New British history in schools must be an honest "warts and all" story', Fabian Society, 16 January (www.fabian-society.org.uk/press_office/ display.asp?cat=43\&id=526).

Fekete, L. (2001) 'The emergence of xeno-racism', Race and Class, vol 43, no 2: 24-40.

Fekete, L. (2004) 'Anti-Muslim racism and the European security state', Race and Class, vol 46, no 1: 3-29. Garner, R. (2007) 'Pupils to learn "Britishness" in history', The Independent, 26 January.

Home Office (2001) Building cohesive communities: A report of the ministerial group on public order and community cohesion, London: Home Office.

Home Office (2004) 'Prince of Wales to attend first citizenship ceremony', press release 066/2004, London: Home Office.

Home Office (2005) 'Exclusion or deportation from the UK on non-conducive grounds: consultation document', Home Office, 5 August (www.homeoffice. gov.uk/documents/consdeportation-05085).

Home Office (2006) A points based system: Making migration work for Britain, London: Home Office.

Johnston, P. (2007) 'Brown's manifesto for Britishness', The Daily Telegraph, 13 January.

Pilger, J. (2006) Freedom next time, London: Bantam Press.

Sivanandan, A. (2006a) 'Race, terror and civil society', Race and Class, vol 47, no 3: 1-8.

Sivanandan, A. (2006b) 'Racism, liberty and the war on terror', Institute of Race Relations

News Network, 18 September (www.irr.org.uk/2006/september/ ak000011.html).

Travis, A. (2003) 'New Britons to pledge loyalty to country', The Guardian, 26 July.

Waites, M. (2007) 'Thousands of "living ghosts" left destitute by Home Office', Yorkshire Post Today, 20 January (www.yorkshiretoday.co.uk/ViewArticle2. aspx).

Waters, H. (2004) 'Editorial', Race and Class, vol 46, no 1: 1-2.

West, P. (2005) The poverty of multiculturalism, London: Civitas.

Woodward, W. (2006) 'Radical Muslims must integrate, says Blair', Guardian Unlimited, 9 December (www.guardian.co.uk/print/0,,329658187-103602,00.html). 